\title{
PENGARUH PENERAPAN PAKET TEKNOLOGI BUDIDAYA TERHADAP KARAKTER PERTUMBUHAN DAN HASIL GENOTIPE TANAMAN JAGUNG (ZEA MAYS L.)
}

\section{THE EFFECT OF CULTIVATION TECHNOLOGY PACKAGE IMPLEMENTATION TO CHARACTER OF GROWTH AND RESULT OF CORN PLANT GENOTYPE (ZEA MAYS L.)}

\author{
Eni Marzia ${ }^{1}$, I Wayan Sutresa ${ }^{2}$, Kisman $^{3}$ \\ Alumni $^{1}$, Dosen Pembimbing Utama ${ }^{2}$, Dosen Pembimbing Pendamping ${ }^{3}$ \\ Program Studi Agroekoteknologi Fakultas Pertanian Universitas Mataram \\ kismanunram@gmail.com
}

\begin{abstract}
ABSTRAK
Jagung (Zea mays L.) merupakan salah satu komoditas strategis dalam pembangunan pertanian dan perekonomian Indonesia. Jagung tidak hanya diperlukan untuk pangan, namun juga lebih banyak dibutuhkan untuk pakan dan bahan baku industri dalam jumlah yang terus meningkat. Untuk memenuhi kebutuhan permintaan jagung, peningkatan produksi masih perlu diupayakan. Penerapan teknologi budidaya merupakan salah satu inovasi yang dapat dilakukan untuk meningkatkan produksi jagung, sehingga dapat memenuhi kebutuhan permintaan jagung. Penelitian ini bertujuan untuk mengetahui pengaruh penerapan paket teknologi budidaya terhadap karakter pertumbuhan dan daya hasil genotipe tanaman jagung (Zea mays L.). Metode penelitian yang digunakan adalah metode eksperimental dengan percobaan lapang. Rancangan percobaan yang digunakan adalah Rancangan Acak Kelompok (RAK), dengan 4 perlakuan teknologi budidaya (T) : yaitu $\mathrm{T}_{1}=$ Varietas Sukmaraga dengan jarak tanam $\left.(35 \mathrm{x} 35) \mathrm{x} 100\right) \mathrm{cm} . \mathrm{T}_{2}=$ Populasi $\mathrm{C}_{2}$ dengan jarak tanam $70 \mathrm{x}$ $20 \mathrm{~cm} . \mathrm{T}_{3}=$ Lokal Bima dengan jarak tanam $70 \times 20 \mathrm{~cm} . \mathrm{T}_{4}=$ Varietas Lamuru dengan jarak tanam (40x30)x60) cm. Masing-masing perlakuan diulang 6 kali sehingga diperoleh 24 unit percobaan. Data hasil pengamatan dianalisis dengan analisis ragam pada taraf 5\% dan dilanjutkan dengan Uji Beda Nyata Jujur (BNJ) pada taraf yang sama. Hasil penelitian menunjukkan bahwa: Penerapan paket teknologi budidaya $\mathrm{T}_{1}$ dan $\mathrm{T}_{4}$ secara statistik memberikan hasil sama atau menunjukkan tidak berbeda nyata terhadap hasil berat kering pipil (gr/tan) serta lebih baik dibandingkan dengan perlakuan paket teknologi $\mathrm{T}_{2}$ dan $\mathrm{T}_{3}$
\end{abstract}

\section{ABSTRACT}

Corn (Zea mays L.) is one of the strategic commodities in the development of agriculture and the economy of Indonesia. Corn is not only needed for food, but also more needed for feed and industrial raw materials in an ever increasing amount. To meet the needs of corn demand, production increase still needs to be sought. The application of cultivation technology is one of the innovations that can be done to increase the production of corn, so it can fulfill demand for corn. This research aims to determine the implementation of the cultivation technology package to the character of the growth and power of plant genotypes (Zea mays L.). The research methods used are experimental methods with a roomy experiment. The experimental design used is Completely Randomize Blocks (RAK), with 4 cultivation technology (T) Treatment: T1 = Sukmaraga varieties with planting distance (35x35) x100) cm. T2 = population C2 with cropping distance $70 \times 20 \mathrm{~cm}$. $T 3$ = local Bima with planting distance $70 \times 20 \mathrm{~cm}$. T4 = variety Lamuru with spacing (40x30) x60) $\mathrm{cm}$. Each treatment is repeated 6 times so that it is obtained 24 units of trial. Data on the observation result is analyzed by various analysis at 5\% and continued with real difference of honest (BNJ) test. The results showed that: the application of the package of cultivation technology T1 and T4 statistically provide the same results or show no distinct real weight results dry Pipil (GR/tan) and better than the package treatment T2 and T3 Technologies.

Kata kunci : Varietas, Jarak Tanam, Daya Hasil

Keyword: Varieties, Spacing, Results 


\section{PENDAHULUAN}

Jagung (Zea mays L.) merupakan salah satu komoditas strategis dalam pembangunan pertanian dan perekonomian Indonesia. Jagung di Nusa Tenggara Barat khususnya di Lombok Barat menjadi salah satu tanaman pangan penting kedua setelah padi yang biasanya dibudidayakan. Dewasa ini jagung tidak hanya diperlukan untuk pangan, namun juga lebih banyak dibutuhkan untuk pakan dan bahan baku industri dalam jumlah yang terus meningkat. Dengan semakin meningkatnya permintaan jagung sebagai bahan pangan, industri dan pakan ternak serta untuk ekspor, harga jagung menjadi meningkat dan dapat memberi keuntungan bagi petani jika menanam jagung (Himawan dan Supriyanto, 2003).

Terdapat sepuluh provinsi sentra produksi jagung yang menguasai sekitar $85 \%$ produksi nasional. Provinsi NTB sebagai salah satu sentra produksi (ke-5 nasional) berkontribusi dalam penyediaan jagung sebesar 7\%. Tercatat luas panen jagung di Nusa Tenggara Barat tahun 2018 seluas 306.899 Ha dengan produksi sebesar 2,06 juta ton dan produktivitas sebesar 6,71 ton/ha (Badan Ketahanan Pangan, 2018).

Berdasarkan data Badan Ketahanan Pangan (2018), produksi jagung Indonesia tahun 2018 yaitu sebesar 30,56 juta ton pipilan kering dengan luas panen 5,73 juta Ha. Produksi jagung dalam 5 tahun terakhir meningkat rata-rata $12,49 \%$ per tahun. Hal ini didukung oleh data luas panen per tahun yang rata-rata meningkat $11,13 \%$ dan produktivitas rata-rata meningkat 1,57\%. Sementara kebutuhan jagung tahun 2018 diperkirakan sebesar 23,58 juta ton pipilan kering. Artinya terdapat surplus sebesar 9,77 juta ton pipilan kering dan bahkan Indonesia telah ekspor jagung ke Filipina dan Malaysia sebanyak 372.990 ton. Kebutuhan tersebut dapat dicukupi dari hasil produksi di dalam negeri dan bahkan terdapat surplus. Oleh karena itu perlu produksi jagung perlu dipertahankan agar dapat mencapai swasembada jagung.

Untuk mencapai swasembada dan memenuhi kebutuhan permintaan jagung, peningkatan produksi masih perlu diupayakan. Menurut Subandi dan Zubachtirodin (2005), keberhasilan peningkatan produksi jagung sangat tergantung pada kemampuan penyediaan dan penerapan inovasi teknologi yaitu meliputi varietas unggul baru berdaya hasil dan berkualitas tinggi, penyediaan benih bermutu serta penerapan teknologi budidaya yang tepat. Penggunaan varietas unggul yang dikombinasikan dengan penggunaan pupuk, pengaturan jarak tanam dan pengairan yang tepat merupakan salah satu paket teknologi inovatif yang mampu meningkatkan produktivitas tanaman jagung. Selain untuk meningkatkan produktivitas tanaman, penerapan teknologi budidaya jagung mengutamakan pemanfaatan sumberdaya lokal, serta mempertimbangkan kearifan lokal petani (Puslitbangtan, 2009).

Teknologi budidaya yang dikemas dalam beberapa paket teknologi seperti penggunaan varietas unggul, pupuk dan jarak tanam sangat berperan penting dalam mengatasi sebagian masalah yang dihadapi dalam meningkatkan produksi jagung. Selain potensi produktivitas dan ketahanannya terhadap hama penyakit, karakter tanaman lain yang perlu dipertimbangkan dalam pemilihan varietas jagung unggul adalah kesesuaiannya dengan kondisi lingkungan (tanah dan iklim), antara lain toleran kekeringan dan tanah masam, serta prefrensi petani terhadap karakter lainnya seperti umur dan warna biji. Berdasarkan uraian-uraian tersebut, maka telah dilakukan penelitian ini yang bertujuan untuk mengetahui pengaruh penerapan paket teknologi budidaya terhadap karakter pertumbuhan dan hasil genotipe tanaman jagung (Zea mays).

Penelitian ini bertujuan untuk mengetahui pengaruh penerapan paket teknologi budidaya terhadap karakter pertumbuhan dan daya hasil genotype tanaman jagung (Zea mays L.). Manfaat yang ingin dicapai yaitu hasil dari penelitian ini diharapkan dapat memberi kontribusi untuk meningkatkan produksi jagung di Nusa Tenggara Barat melalui penerapan teknologi budidaya yang tepat. Hipotesis yang diajukan: minimal satu atau lebih paket teknologi budidaya yang dapat mempengaruhi pertumbuhan dan hasil tanaman jagung (Zea mays L.).

\section{METODE PENELITIAN}

Metode yang digunakan dalam penelitian ini adalah metode eksperimental dengan percobaan di lapang. Percobaan ini telah dilaksanakan di Desa Dasan Tebu, Kecamatan Gerung, Kabupaten Lombok Barat pada lahan berpengairan setengah teknis (MK II) yang terletak pada ketinggian $21 \mathrm{~m}$ dpl. Percobaan dilakukan pada bulan Juli sampai dengan bulan November 2018. Alat-alat yang digunakan dalam percobaan ini adalah cangkul, sabit, papan nama, penggaris kayu, timbangan, jangka sorong, ember, staples besar dan kecil, kantong plastik, kertas label, lakban dan alat tulis menulis. Bahan-bahan yang digunakan dalam percobaan ini adalah Jagung Varietas Lamuru, Sukmaraga, Populasi C2, Lokal Bima, Pupuk Urea, Pupuk Ponska, Pupuk Organik, Saromyl 35 SD dan Furadan 3 G. Rancangan percobaan yang digunakan dalam penelitian ini adalah Rancangan Acak Kelompok yang terdiri atas 4 perlakuan paket teknologi budidaya (T) yaitu :

T1 $_{1}$ : Varietas Sukmaraga + pupuk organik $15 \mathrm{t} / \mathrm{ha}+$ pupuk urea $200 \mathrm{~kg} / \mathrm{ha}+$ pupuk NPK Phonska 250 $\mathrm{kg} / \mathrm{ha}+$ jarak tanam $(35 \times 35) \times 100) \mathrm{cm} ; \mathbf{T}_{2}$ : Populasi $\mathrm{C}_{2}+$ pupuk organik $15 \mathrm{t} / \mathrm{ha}+$ pupuk urea $200 \mathrm{~kg} / \mathrm{ha}+$ pupuk NPK Phonska $250 \mathrm{~kg} / \mathrm{ha}+$ jarak tanam 70 × $20 \mathrm{~cm}$; $\mathbf{T}_{3}$ : Lokal Bima pupuk organik $15 \mathrm{t} / \mathrm{ha}+$ pupuk 
urea $200 \mathrm{~kg} / \mathrm{ha}+$ pupuk NPK Phonska $250 \mathrm{~kg} / \mathrm{ha}+$ jarak tanam 70 × $20 \mathrm{~cm} ; \mathbf{T}_{\mathbf{4}}:$ Varietas Lamuru + pupuk organik $15 \mathrm{t} / \mathrm{ha}+$ pupuk urea $200 \mathrm{~kg} / \mathrm{ha}+$ pupuk NPK Phonska $250 \mathrm{~kg} / \mathrm{ha}+$ jarak tanam (40x30)x60) cm; masing-masing perlakuan diulang sebanyak 6 kali sehingga memeperoleh 24 unit percobaan.

Persiapan lahan. Tanah yang akan digunakan sebagai tempat percobaan sebelumnya dibajak dan digaru terlebih dahulu sebanyak satu kali kemudian diratakan. Selanjutnya dibuat 6 blok masing-masing berukuran (6x10) $\mathrm{m}$ yang terbagi dalam 4 plot. Jarak antar blok yaitu $1 \mathrm{~m}$ dan jarak antar plot 0,5 m. Pada masing-masing plot ditempatkan perlakuan paket teknologi secara acak. Persiapan benih. Benih yang akan ditanam terlebih dahulu diperlakukan dengan Saromyl 35 SD dengan dosis $5 \mathrm{~g} / \mathrm{kg}$ benih. Perlakuanya dilakukan secara terpisah antar varietas agar tidak tercampur antara varietas yang satu dengan yang lain. Penanaman dilakukan dengan cara tugal, dibuat lubang sedalam kurang lebih $5 \mathrm{~cm}$. Setiap lubang ditanami 2 biji benih jagung dan Furadan $1 \mathrm{~kg} / \mathrm{ha}$ untuk mencegah serangan lalat bibit.

Penjarangan dilakukan saat tanaman berumur 21 hari setelah tanam. Penjarangan dilakukan dengan mencabut tanaman yang lebih dari 2 tanaman per lubang. Selanjutnya dilakukan penyulaman yang bertujuan untuk mengganti benih yang tidak tumbuh/mati. Jumlah dan jenis benih serta perlakuan dalam penyulaman sama dengan sewaktu penanaman. Penyiangan dilakukan pada saat tanaman berumur 21 hari setelah tanam. Penyiangan dilakukan 2 minggu sekali. Pemupukan dilakukan dengan 2 tahap yaitu pupuk dasar dan pupuk sususlan. Pemupukan dasar dengan pupuk organik (kandang atau kompos) sesuai dengan dosis perlakuan dalam paket, diberikan bersamaan pada saat penanaman sebagai penutup lubang tanam. 2/3 pupuk Urea dari dosis $200 \mathrm{~kg} / \mathrm{ha}$ dan pupuk NPK Phonska $250 \mathrm{~kg} / \mathrm{ha}$ juga dilberikan sebagai pupuk dasar. Selanjutnya 1/3 Urea sisa dari pemupukn dasar digunakan pada saat pupuk susulan bersamaan dengan penyiangan dan pembumbunan pada umur tanaman 21 hari setelah tanam. Pembumbunan dilakukan saat tanaman berumur 21 hari setelah tanam bersamaan dengan waktu pemupukan. Pembumbunan dilakukan untuk memperkokoh posisi batang agar tanaman tidak mudah rebah dan menutup akar yang bermunculan di atas permukaan tanah karena adanya aerasi. Pengairan dilakukan hanya satu kali yaitu pada saat pengolahan tanah sebelum penanaman dimulai. Pengairan dilakukan dengan cara digenangi, tujuannya yaitu agar tanah dalam kondisi kapasitas lapang. Selanjutnya tidak dilakukan penyiraman dikarenakan selama percobaan berlagsung tanah masih dalam kondisi kapasitas lapang. Panen jagung dilakukan apabila 85\% dari tanaman jagung untuk setiap perlakuan telah memenuhi kriteria panen, yaitu daun dan kelobot telah kering, apabila biji dipijit tidak berbekas dan rambut jagung sudah berwarna kehitaman. Selanjutnya dilkukan pengeringan dengan cara dijemur di bawah sinar matahari sampai mencapai kadar air $14 \%$ setelah itu dipipil kemudian ditimbang menggunakan timbangan analitik.

Pengamatan dilakukan terhadap karakter pertumbuhan, hasil dan komponen hasil tanaman jagung yaitu; Tinggi tanaman $(\mathrm{cm})$, Diameter batang $(\mathrm{cm})$, Jumlah daun (helai), Panjang daun $(\mathrm{cm})$, Lebar Daun (cm), Umur Keuar Malai (Hari Setelah Tanam), Umur Keluar Rambut Tongkol (Hari Setelah Tanam), Umur Panen (Hari Setelah Tanam), Panjang tongkol (cm), Diameter tongkol (cm), Berat 100 butir biji (gr), Berat biji kering pipil (gr/tan)

Data hasil pengamatan dianalisis dengan analisis ragam pada taraf nyata 5\% dan dilakukan uji lanjut dengan Uji Beda Nyata Jujurl (BNJ) pada taraf yang sama. Model analisis ragam untuk data hasil pengamatan disajikan pada Tabel 4.1 .

Tabel 4.1. Analisis Keragaman (Anova) dengan taraf nyata 5\%

\begin{tabular}{llllll}
\hline SK & DB & JK & KT & F hitung & F tabel (5\%) \\
\hline Perlakuan & $(\mathrm{r}-1)$ & JKB & KTB & KTB/KTG & DBB/DBG \\
Blok & $(\mathrm{t}-1)$ & JKP & KTP & KTP/KTG & DBP/KTG \\
Galat & $(\mathrm{r}-1)(\mathrm{t}-1)$ & JKG & KTG & & \\
Total & $(\mathrm{t} . \mathrm{r}-1)$ & JKT & & & \\
\hline
\end{tabular}

Keterangan : SK = Sumber Keragaman; DB = Derajat Bebas; JK = Jumlah Kuadrat; KT = Kuadrat Tengah; $r$ = ulangan; $\mathrm{t}=$ perlakuan; $\mathrm{JKB}=$ Jumlah Kuadrat Blok; JKP = Jumlah Kuadrat Perlakuan; JKG = Jumlah Kuadrat Galat; JKT = Jumlah Kuadrat Total; KTB = Kuadrat Tengah Blok; KTP = Kuadrat Tengah Perlakuan; KTG = Kuadrat Tengah Galat.

Cara Menghitung Nilai Heritabilitas ;

$\sigma^{2} \mathrm{G}=\frac{K T P-K T E}{r}$

$\sigma^{2} \mathrm{P}=\sigma^{2} G+K T E$

$\mathrm{H}^{2}=\frac{\sigma^{2} G}{\sigma^{2} P} \times 100 \%$ 
Cara Menghitung Koefisien Keragaman Genetik ;

$\mathrm{KKG}=\frac{\sqrt{\sigma^{2} G}}{\text { Rerata Unum }} \times 100 \%$

\section{HASIL DAN PEMBAHASAN}

\subsection{Hasil}

Hasil analisis keragaman (Anova) dengan taraf nyata 5\% pada Tabel 4.1 menunjukkan bahwa ada perbedaan antar pengaruh perlakuan paket teknologi budidaya terhadap karakter pertumbuhan dan hasil tanaman jagung. Selanjutnya dilakukan uji lanjut BNJ pada taraf nyata 5\% untuk mengetahui perlakuan mana saja yang berbeda nyata dan tidak berbeda nyata, seperti yang tersaji pada Tabel 4.2. Nilai heritabilitas untuk semua karakter yang diamati menunjukkan nilai yang termasuk dalam kriteria tinggi sedangkan nilai koefisien keragaman genetik (KKG) yang diperoleh menunjukkan nilai dengan kriteria rendah hingga tinggi seperti yang tersaji pada Tabel 4.3.

Tabel 4.1 Rangkuman Kuadrat Tengah Seluruh Karakter yang di amati Berdasarkan Analisis Keragaman (Anova)

\begin{tabular}{|c|c|c|c|c|}
\hline \multirow{2}{*}{ No. } & \multirow{2}{*}{ Karakter yang di amati } & \multicolumn{3}{|c|}{ Kuadrat Tengah } \\
\hline & & Perlakuan & Blok & Galat \\
\hline 1. & Tinggi tanaman $(\mathrm{cm})$ & $3069,65^{* *}$ & $171,334^{\mathrm{ns}}$ & 138,245 \\
\hline 2. & Jumlah daun (helai) & $10,243^{* *}$ & $0,164^{\mathrm{ns}}$ & 0,233 \\
\hline 3. & Panjang daun $(\mathrm{cm})$ & $37,315^{* *}$ & $5,234^{\mathrm{ns}}$ & 1,983 \\
\hline 4. & Lebar daun $(\mathrm{cm})$ & $2,660^{* *}$ & $0,278^{\mathrm{ns}}$ & 0,180 \\
\hline 5. & Diameter batang (cm) & $0,146^{* *}$ & $0,013^{*}$ & 0,003 \\
\hline 6. & Umur keluar malai (hst) & $29,819^{* *}$ & $0,342^{\mathrm{ns}}$ & 0,253 \\
\hline 7. & Umur keluar rambut tongkol (hst) & $0,253^{* *}$ & $0,242^{\mathrm{ns}}$ & 0,219 \\
\hline 8. & Umur panen (hst) & $815,375^{* *}$ & $0,543^{\mathrm{ns}}$ & 0,208 \\
\hline 9. & Panjang tongkol $(\mathrm{cm})$ & $5,629^{*}$ & $0,350^{\mathrm{ns}}$ & 0,608 \\
\hline 10. & Diameter tongkol $(\mathrm{cm})$ & $1,729^{* *}$ & $0,031^{\mathrm{ns}}$ & 0,028 \\
\hline 11. & Berat 100 biji kering pipil (gr) & $165,834^{* *}$ & $1,885^{\mathrm{ns}}$ & 1,945 \\
\hline 12. & Berat biji kering pipil (gr/tan) & $26592,51^{* *}$ & $115,851^{\mathrm{ns}}$ & 140,861 \\
\hline
\end{tabular}

Keterangan : $\mathrm{ns}=$ tidak berbeda nyata $; *=$ berbeda nyata $; * *=$ sangat berbeda nyata

Berdasarkan Tabel 4.1 dapat dilihat bahwa pengaruh blok atau kelompok hanya berbeda nyata pada diameter batang dan tidak berbeda nyata pada 11 variabel lain yang diamati. Adapun pengaruh perlakuan berbeda nyata terhadap panjang tongkol dan sangat berbeda nyata terhadap tinggi tanaman, jumlah daun, panjang daun, lebar daun, diameter batang, umur keluar malai, umur keluar rambut tongkol, umur panen, diameter tongkol, berat 100 biji kering pipil, dan berat biji kering pipil per tanaman. Hal ini menunjukkan bahwa penerapan paket teknologi budidaya tanaman memberikan pengaruh yang berbeda terhadap pertumbuhan dan hasil tanaman jagung.

Pada Tabel 4.2. hasil analisis data uji lanjut menggunakan BNJ dengan taraf nyata 5\% dapat diketahui bahwa pengaruh perlakuan paket teknologi budidaya $T_{1}$ dan $T_{4}$ menunjukkan tidak berbeda nyata terhadap hasil tanaman jagung (berat biji kering pipil per tanaman). Namun menunjukkan berbeda nyata dengan perlakuan $T_{2}$ dan $T_{3}$. Dapat dilihat pada karakter berat biji kering pipil per tanaman, perlakuan $T_{1}$ dan $T_{4}$ diikuti oleh huruf yang sama artinya tidak berbeda nyata. Adapun pada karakter tinggi tanaman, jumlah daun, umur keluar malai, umur keluar rambut tongkol, umur panen,diameter tingkol berat 100 biji kering pipil, dan berat biji kering pipil per tanaman, perlakuan $T_{3}$ dan $T_{4}$ menunjukkan berbeda nyata. Selanjutnya pada karakter panjang tongkol, semua perlakuan $\left(\mathrm{T}_{1}, \mathrm{~T}_{2}, \mathrm{~T}_{3}\right.$ dan $\left.\mathrm{T}_{4}\right)$ tidak menunjukkan berbeda nyata.

Pada Tabel 4.3 seluruh karakter yang diamati (tinggi tanaman, jumlah daun, panjang daun, lebar daun, diameter batang, umur keluar malai, umur keluar rambut tongkol, umur panen, panjang tongkol, diameter tongkol, berat 100 biji kering pipil dan berat biji kering pipil per tanaman) diperoleh nilai heritabilitas yang tinggi, sementara pada perhitungan nilai koefisien keragaman genetik menunjukkan nilai dengan kriteria rendah hingga tinggi. Karakter yang menunjukkan nilai koenfisien keragaman genetik rendah yaitu karakter panjang daun, lebar daun, dimeter batang, umur keluar malai, umur keluar rambut tongkol, panjang tongkol dan diameter tongkol.

Tabel 4.2 Hasil Analisis Uji Lanjut BNT pada Taraf Nyata 5\% Seluruh Karakter yang diamati 


\begin{tabular}{|c|c|c|c|c|c|c|}
\hline \multirow{2}{*}{ No } & \multirow{2}{*}{ Karakter yang diamati } & \multicolumn{4}{|l|}{ Perlakuan } & \multirow{2}{*}{$\begin{array}{l}\text { Nilai BNJ } \\
5 \%\end{array}$} \\
\hline & & $\mathrm{T}_{1}$ & $\mathrm{~T}_{2}$ & $\mathrm{~T}_{3}$ & $\mathrm{~T}_{4}$ & \\
\hline 1. & Tinggi tanaman $(\mathrm{cm})$ & $239,2 \mathrm{ab}$ & $204,15 \mathrm{ab}$ & $202,6 a$ & $245,383 b$ & 41,569 \\
\hline 2. & Jumlah daun (helai) & $15,75 b c$ & $14,6 \mathrm{ab}$ & $13,783 \mathrm{a}$ & $16,767 \mathrm{c}$ & 1,707 \\
\hline 3. & Panjang daun $(\mathrm{cm})$ & $97,833 b$ & $92,792 \mathrm{a}$ & $95,433 \mathrm{ab}$ & $98,167 b$ & 4,979 \\
\hline 4. & Lebar daun $(\mathrm{cm})$ & $9,192 b$ & $8,267 \mathrm{ab}$ & $7,567 \mathrm{a}$ & $8,383 \mathrm{ab}$ & 1,501 \\
\hline 5. & Diameter batang $(\mathrm{cm})$ & $2,113 \mathrm{c}$ & $1,766 \mathrm{a}$ & $1,821 \mathrm{ab}$ & $1,972 b c$ & 0,204 \\
\hline 6. & Umur keluar malai (hst) & $54,67 \mathrm{c}$ & $50,33 \mathrm{ab}$ & $49,5 \mathrm{a}$ & $53,33 c$ & 1,777 \\
\hline 7. & $\begin{array}{l}\text { Umur keluar rambut tongkol } \\
\text { (hst) }\end{array}$ & $56,50 \mathrm{c}$ & $53,3 b$ & $51,833 \mathrm{a}$ & $54,67 \mathrm{bc}$ & 1,748 \\
\hline 8. & Umur panen (hst) & $102,50 \mathrm{~d}$ & $82,50 \mathrm{~b}$ & $80,333 a$ & $100,50 \mathrm{c}$ & 1,614 \\
\hline 9. & Panjang tongkol $(\mathrm{cm})$ & $15,956 a$ & $15,144 \mathrm{a}$ & $14,057 \mathrm{a}$ & $16,206 a$ & 2,756 \\
\hline 10. & Diameter tongkol $(\mathrm{cm})$ & $7,682 b$ & $7,115 b$ & $6,392 \mathrm{a}$ & $7,256 \mathrm{~b}$ & 0,594 \\
\hline 11. & $\begin{array}{l}\text { Berat } 100 \text { biji kering pipil } \\
\text { (gr) }\end{array}$ & $32,77 \mathrm{c}$ & $27,295 b$ & $20,849 a$ & $30,921 b c$ & 4,854 \\
\hline 12. & Berat biji kering pipil (gr/tan) & $266,327 c$ & $181,95 b$ & $122,185 a$ & $251,33 \mathrm{c}$ & 41,960 \\
\hline
\end{tabular}

Keterangan ; Angka pada baris yang sama diikuti oleh huruf yang berbeda menunjukkan berbeda nyata, dan angka yang diikuti oleh huruf yang sama menunjukkan tidak berbeda nyata pada uji BNJ dengan taraf nyata $5 \%$.

Karakter yang menunjukkan nilai koenfisien keragaman genetik agak rendah yaitu tinggi tanaman, jumlah daun, dan umur panen. Karakter yang menunjukkan nilai koenfisien keragaman genetik cukup tinggi yaitu berat 100 biji kering pipil. Sementara karakter yang menunjukkan nilai koenfisien keragaman genetik tinggi yaitu berat biji kering pipil per tanaman.

Tabel 4.3 Hasil Analisis Pendugaan Nilai Heritabilitas dan Koefisien Keragaman Genetik (KKG) Seluruh Variabel Pengamatan

\begin{tabular}{|c|c|c|c|c|c|c|c|}
\hline No & Karakter yang diamati & $\boldsymbol{\sigma}^{2} \mathrm{G}$ & $\boldsymbol{\sigma}^{2} \mathrm{P}$ & $\mathrm{H}^{2}$ & Kriteria & $\begin{array}{l}\text { KKG } \\
\%\end{array}$ & Kriteria \\
\hline 1. & Tinggi tanaman $(\mathrm{cm})$ & 488,567 & 626,816 & 77,94 & 4 & 9,91 & 1 \\
\hline 2. & Jumlah daun (helai) & 1668 & 1,901 & 87,73 & 4 & 8,48 & 1 \\
\hline 3 . & Panjang daun $(\mathrm{cm})$ & 5,888 & 7,872 & 74,80 & 4 & 2,53 & 2 \\
\hline 4. & Lebar daun $(\mathrm{cm})$ & 0,413 & 0,593 & 69,66 & 4 & 7,69 & 2 \\
\hline 5. & Diameter batang $(\mathrm{cm})$ & 0,024 & 0.028 & 87,69 & 4 & 8,05 & 2 \\
\hline 6. & Umur keluar malai (hst) & 4,928 & 5,1805 & $95,1294,09$ & 4 & 4,27 & 2 \\
\hline 7. & $\begin{array}{l}\text { Umur keluar rambut } \\
\text { tongkol (hst) }\end{array}$ & 3,894 & 4,139 & $99,8457,9390,9493,54$ & 4 & 3,64 & 2 \\
\hline 8. & Umur panen (hst) & 135,861 & 136,069 & 96,91 & 4 & 12,74 & 1 \\
\hline 9. & Panjang tongkol $(\mathrm{cm})$ & 0,837 & 1,445 & & 4 & 5,96 & 2 \\
\hline 10. & Diameter tongkol $(\mathrm{cm})$ & 0,283 & 0,312 & & 4 & 7,49 & 2 \\
\hline 11. & $\begin{array}{l}\text { Berat } 100 \text { biji kering pipil } \\
\text { (gr) }\end{array}$ & 27,325 & 29,209 & & 4 & 18,69 & 34 \\
\hline 12. & $\begin{array}{l}\text { Berat biji kering pipil } \\
\text { (gr/tan) }\end{array}$ & 4408,607 & 4549,469 & & 4 & 32,32 & 4 \\
\hline
\end{tabular}

Keterangan ; $\mathrm{H}^{2}=$ Heritabilitas arti luas; $\mathrm{KKG}=$ Koefisien Keragaman Genetik; $\sigma^{2} \mathrm{G}=$ Ragam Genotipe; $\sigma^{2} \mathrm{P}=$ Ragam Fenotipe. 1= Agak Rendah, 2= rendah, 3= cukup, 4=tinggi

\subsection{Pembahasan}

Pengaruh perlakuan paket teknologi budidaya terhadap karakter pertumbuhan tanaman jagung dapat pada dilihat dari nilai rata-rata yang diperoleh dari beberapa karakter yang diamati seperti tinggi tanaman, jumlah daun, panjang daun, lebar daun dan diameter batang. Sementara komponen hasil dan hasil tanaman jagung dapat dilihat dari karakter panjang tongkol, diameter tongkol, berat 100 biji dan berat biji kering pipil per tanaman.

Analisis uji lanjut BNJ dengan taraf nyata 5\% pada Tabel 4.2. menunjukkan bahwa perlakuan paket teknologi budidaya $T_{1}$ dan $T_{4}$ secara statistik menunjukkan tidak berbeda nyata terhadap hasil tanaman jagung dan menunjukkan berbeda nyata dengan perlakuan $T_{2}$ dan $T_{3}$. Dapat dilihat dari analisis uji lanjut BNJ 
terhadap karakter berat kering pipil per tanaman. Hal ini didukung oleh nilai rata-rata yang diperoleh pada karakter jumlah daun, diameter batang, umur keluar malai, umur keluar rambut tongkol, dan berat 100 biji kering pipil. Dapat dilihat pada Grafik Histogram pengaruh perlakuan teknologi budidaya tanaman jagung terhadap hasil biji kering pipil disajikan pada Gambar 1.

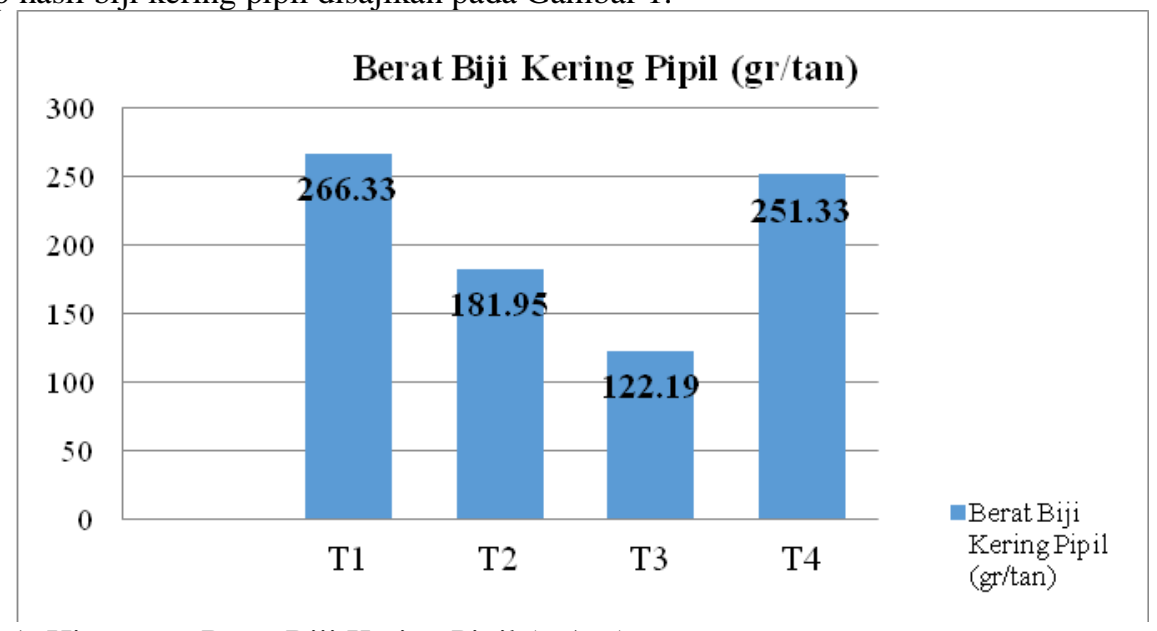

Gambar 1: Histogram Berat Biji Kering Pipil (gr/tan)

Adanya perbedaan hasil dari setiap genotipe yang dicobakan disebabkan karena adanya perbedaan susunan genetik serta faktor lingkungan tumbuh. Perbedaan genetik ini mengakibatkan setiap varietas memiliki ciri dan sifat khusus yang berbeda satu sama lain sehingga menunjukkan keragaman penampilan. Begitupula dengan lingkungan tumbuh suatu tanaman akan mempengaruhi pertumbuhan maupun hasil produksi tanaman. Tanaman dengan lingkungan tumbuh yang baik seperti tercukupinya unsur hara yang tersedia di dalam tanah sebagai makanan bagi tanaman tersebut, maka akan memberikan hasil yang optimal pula bagi tanaman baik dari segi pertumbuhan dan hasil produksinya.

Penambahan pupuk organik dan pengaturan jarak tanam juga berpengaruh terhadap pertumbuhan dan hasil produksi suatu tanaman. Sebagaimana pernyataan Sutresna (2016), dengan penambahan pupuk organik $(15-20)$ ton/ha. disertai pengaturan serta variasi kerapatan tanam dari (20x70) $\mathrm{cm}$ menjadi (35x35) x70 cm (sistem jajar penganten) dapat memperbaiki tinggi tanaman, bobot brangkasan segar, bobot 100 butir biji kering, panjang tongkol, diameter tongkol dan bobot hasil biji kering pipil. Hal ini sejalan dengan hasil yang diperoleh pada percobaan yang telah dilakukan. Perlakuan T1 dan T4 dengan jarak tanam yang lebih rapat yaitu masing-masing berukuran $(35 \times 35) \times 100) \mathrm{cm}$ dan $(40 \times 30) \times 60) \mathrm{cm}$, dapat mempengaruhi hasil berat kering pipil yang lebih tinggi dibandingkan dengan pengaturan jarak tanam biasa seperti pada perlakuan $\mathrm{T} 2$ dan T3.

Jarak tanam merupakan faktor penting untuk mendapatkan hasil yang tinggi pada tanaman jagung karena jagung dipengaruhi oleh jumlah tanaman pada kestuan luas. Dengan pengaturan sistem jarak tanam lebih sempit akan meningkatkan produksi persatuan luas lahan. Kerapatan tanam harus diatur dengan jarak tanam optimal sehingga tidak terjadi persaingan antar tanaman, mudah dalam melakukan pemeliharaan serta mengurangi biaya. Kerapatan tanaman mempengaruhi penampilan dan produksi tanaman, terutama karena koefisien penggunaan cahaya.

Tanaman jagung memerlukan nitrogen dalam jumlah relatif banyak sebagai bahan penyusun protein dan protoplasma serta pembentuk bagian tanaman seperti batang dan daun. Salisbury dan Ross (1991) menyatakan kapasitas fotosintesis meningkat dengan bertambahnya jumlah daun pada tanaman jagung. Terjadinya perbedaan dari setiap genotipe yang diuji diduga merupakan pengaruh perbedaan genetik dan perbedaan lingkungan tumbuh. Menurut Gardner et al., (1991), pada beberapa komponen pengamatan seperti jumlah daun tanaman, dipengaruhi oleh genotipe dan lingkungan. Posisi daun dikendalikan oleh genotipe tanaman yang berpengaruh nyata terhadap laju pertumbuhan daun sehingga jumlah daun berbeda dari masing-masing varietas jagung yang digunakan.

Selain dipengaruhi oleh penambahan pupuk organik dan pengaturan jarak tanam, tinggi rendahnya biji yang dihasilkan juga dipengaruhi oleh cocok tidaknya genotipe yang digunakan tersebut dengan kondisi penanaman. Mengingat masing-masing genotipe memiliki susunan gen yang berbeda dan memiliki sifat spesifik terhadap (lingkungan tumbuh). Oleh karena itu pemilihan genotipe merupakan salah satu faktor sangat penting dalam menentukan keberhasilan budidaya tanaman jagung.

Penggunaan varietas unggul, pemupukan dan pengelolaan budidaya yang tepat dapat meningkatkan produktivitas tanaman jagung. Hal ini dilaporkan dalam penelitian yang dilakukan Balai Penelitian Tanaman Serealia pada lahan kering dengan menerapkan komponen teknologi budidaya pada jagung, produksi 
Varietas Lamuru mencapai 6 - 6,5 ton/ha, Varietas Sukmaraga pada lahan kering masam mencapai 5,5 - 6 ton/ha, dan pada lahan sawah tadah hujan Varietas Lamuru dan Srikandi Kuning memberikan hasil sekitar 67 ton/ha.

\section{Heritabilitas dan Koefisien Keragaman Genetik}

Heritabilitas merupakan parameter genetik yang digunakan untuk mengukur kemampuan suatu genotipe tanaman dalam mewariskan karakter yang dimilikinya atau suatu penduga untuk mengukur seberapa besar hubungan antara keragaman genetik dan keragaman fenotipe dari suatu individu tanaman (Syukur, 2012). Nilai heritabilitas diperlukan untuk mengetahui apakah suatu karakter dipengaruhi oleh faktor genetik atau lingkungan. Stansfield (1991) membagi nilai heritabilitas menjadi tiga kelas yaitu heritabilitas rendah (< $0.2)$, sedang $(0.2 \leq \mathrm{x} \leq 0.5)$, dan tinggi $(0.5 \mathrm{x} \leq 1.0)$. Nilai heritabilitas yang tinggi menunjukkan karakter tersebut lebih dominan dipengaruhi faktor genetik dibandingkan lingkungan. Sebaliknya nilai heritabilitas rendah berarti karakter tersebut lebih dominan dipengaruhi oleh faktor lingkungan.

Nilai heritabilitas dari setiap karakter yang diamati pada percobaan yang dilakukan dapat dilihat pada Tabel 4.3 . Berdasarkan hasil analisis, semua karakter yang diamati memiliki nilai heritabilitas dalam arti luas termasuk dalam kriteria tinggi yaitu berkisar antara 57,93\% hingga 96,91\%. Karakter Berat biji kering pipil per tanaman memiliki nilai heritabilitas tertinggi yaitu 96,91\%. Karakter tinggi tanaman memiliki nilai heritabilitas sebesar $77,94 \%$, nilai heritabilitas jumlah daun sebesar $87,73 \%$, nilai heritabilitas panjang daun sebesar $74,80 \%$, nilai heritabilitas lebar daun sebesar $69,66 \%$, nilai heritabilitas diameter batang sebesar $87,69 \%$, nilai heritabilitas umur keluar malai, umur keluar rambut tongkol, dan umur panen berturut-turut yaitu sebesar 95,12\%; 94,09\%; dan 99,84\%. Nilai heritabilitas panjang tongkol sebesar 57,93\%, nilai heritabilitas diameter tongkol sebesar 90,94\%, dan nilai heritabilitas berat 100 biji sebesar 93,54\%. Hal ini mengindikasi seluruh karakter tersebut didominasi oleh faktor genetik, sehigga karakter yang demikian mudah diwariskan pada generasi berikutnya. Nilai heritabilitas rendah untuk suatu karakter menggambarkan karakter tersebut sangat dipengaruhi oleh faktor lingkungan, pewarisannya sulit sehingga seleksi hanya efektif dilakukan pada generasi lanjut (Fehr, 1987).

Penampilan suatu karakter tanaman akan optimal jika tanaman tersebut berada pada lingkungan yang sesuai, sebaliknya penampilan tidak akan optimal jika berada pada lingkungan yang tidak sesuai. Penampilan suatu karakter yang heritabilitasnya tinggi memiliki pengaruh lingkungan sedikit sehingga penampilannya akan relatif tetap, tetapi karakter yang heritabilitasnya rendah memiliki pengaruh lingkungan yang besar sehingga penampilannya mudah berubah, oleh karena itu lingkungan harus optimal.

Koefisien keragaman genetik (KKG) adalah nisbah besaran simpangan baku genetik dengan nilai tengah populasi karakter yang bersangkutan. Menurut Bahar dan Zen (1993), KKG digunakan untuk mengukur keragaman genetik suatu sifat tertentu dan untuk membandingkan keragaman genetik berbagai sifat tanaman. Tingginya nilai KKG menunjukkan peluang terhadap usaha-usaha perbaikan yang efektif melalui seleksi. Berdasarkan pada nilai parameter genetic tersebut dapat dilakukan seleksi terhadap karakter kuantitatif tanpa mengabaikan nilai tengah populasi yang bersangkutan.

Menurut Moedjiono dan Mejaya, (1994) kriteria KKG relatif yaitu: rendah $(0 \%<\mathrm{x} \leq 25 \%)$, agak rendah $(25 \%<\mathrm{x} \leq 50 \%)$, cukup tinggi $(50 \%<\mathrm{x} \leq 75 \%)$, dan tinggi $(75 \%<\mathrm{x} \leq 100 \%)$. Berdasarkan kriteria tersebut, dengan menggunakan nilai absolut $32,32 \%$ dari hasil penelitian sebagai nilai relatif $100 \%$ maka kisaran nilai absolut kriteria KKG penelitian ini adalah: rendah $(0 \%<\mathrm{x} \leq 8,08 \%)$, agak rendah $(8,08 \%<\mathrm{x} \leq$ $16,16 \%)$, cukup tinggi $(16,16 \%<x \leq 24,24 \%)$, dan tinggi $(24,24 \%<x \leq 32,32 \%)$. Karakter yang memiliki nilai koefisien keragaman genetik yang rendah adalah panjang daun, lebar daun, diameter batang, umur keluar malai, umur keluar rambut tongkol, panjang tongkol dan diameter tongkol. Karakter yang memiliki nilai koefisien keragaman genetik yang agak rendah adalah tinggi tanaman, jumlah daun dan umur panen. Karakter yang memiliki nilai koefisien keragaman genetik yang cukup tinggi adalah berat 100 butir biji. Sedangkan karakter yang memiliki nilai koefisien keragaman genetik yang tinggi adalah berat biji kering pipil per tongkol.

Keragaman genetik dengan kriteria rendah hingga agak rendah berarti keragaman genetiknya sempit dan kriteria agak tinggi hingga tinggi berarti keragaman genetiknya luas. Keragaman genetik sempit terjadi karena karakter pada genptipe yang digunakan tidak memiliki variasi sifat yang lebar pada karakter tersebut. Sedangkan keragaman genetik yang luas dikarenakan setiap karakter genotype yang digunakan mempunyai sifat yang bervariasi. 


\section{KESIMPULAN DAN SARAN}

\subsection{Kesimpulan}

Berdasarkan data dan hasil pembahasan dapat diambil beberapa kesimpulan yaitu sebagai berikut ; Penerapan paket teknologi budidaya tanaman jagung memberikan pengaruh yang berbeda terhadap karakter pertumbuhan dan hasil tanaman jagung. Paket teknologi budidaya $T_{1}$ (Varietas Sukmaraga, jarak tanam $(35 \times 35) \times 100) \mathrm{cm}$ ) dan $\mathrm{T}_{4}$ (Varietas Lamuru, jarak tanam $\left.(40 \times 30) \times 60\right) \mathrm{cm}$ ) secara statistik memberikan hasil sama atau menunjukkan tidak berbeda nyata terhadap hasil berat kering pipil $(\mathrm{gr} / \mathrm{tan})$ serta lebih baik dibandingkan dengan perlakuan paket teknologi $T_{2}$ (Populasi $C_{2}$, jarak tanam $70 \times 20 \mathrm{~cm}$ ) dan $T_{3}$ (Lokal Bima, jarak tanam $70 \times 20 \mathrm{~cm}$ ). Rata-rata hasil berat biji kering pipil paket teknologi $\mathrm{T}_{1}$ dan $\mathrm{T}_{4}$ masingmasing yaitu sebesar $226,33 \mathrm{gr} / \mathrm{tan}$ dan $251,33 \mathrm{gr} / \mathrm{tan}$.

\subsection{Saran}

Dalam melakukan budidaya tanaman jagung, pemilihan genotipe dan teknologi budidaya yang diterapkan merupakan salah satu faktor yang sangat penting dalam menentukan keberhasilan budidaya. Dari hasil percobaan yang telah dilakukan, untuk memperoleh hasil yang lebih tinggi direkomendasikan menggunakan paket $\mathrm{T}_{1}$ dan $\mathrm{T}_{4}$.

\section{DAFTAR PUSTAKA}

Aak. 1993. Budidaya Jagung. Kanisius. Yogyakarta.

Akil, M., M. Rauf, I.U. Firmansyah, Syafruddin, Faesal, R. Efendi, dan A. Kamaruddin. 2005. Teknologi Budidaya Jagung Untuk Pangan Dan Pakan Yang Efisien Dan Berkelanjutan Pada Lahan Marjinal. Balai Penelitian Tanaman Serealia, Maros, p.15-23.

Arianingrum, R. 2004. Kandungan Kimia Jagung Dan Manfaatnya Bagi Kesehatan. Budidaya Pertanian. 1: 128-130.

Awuy, Elsje. 2003. Variabilitas Genetik Beberapa Karakter Kuantitatif Tanaman Kentang Untuk Seleksi Dalam Lingkungan Yang Diberi Penambahan Penyinaran Dan Tanpa Penambahan Penyinaran. Eugenia. 9(1): 22-28.

Badan Ketahanan Pangan Kementrian Pangan RI. 2018. Dikutup dari Artikel ISSN: 26153807.http://bkp.pertanian.go,id/storage/app/uploads/public/5b0/0a8/5b05 230a887ad919144521.pdf. Diakses pada 10 Maret 2019.

Bahar, H., S. Zen. 1993. Parameter genetik pertumbuhan tanaman, hasil dan komponen hasil jagung. Zuriat 4:4-7.

Belfield, Stephanie \& Brown, Christine. 2008. Field Crop Manual. Maize (A Guide To Unpland Production In Cambodia). Canberra.

Barri, N. L. 2003. Peremajaan Kelapa Berbasis Usaha Tani Polikultur Penopang Pendapatan Petani Berkelanjutan. Makalah falsafah Sain (PPs 702) Program Pasca Sarjana/S3. Institut Pertanian Bogor. Desember 2003. Diakses 05 Mei 2019.

Dad Resiworo J.S. 1992. Pengendalian Gulma Dengan Pengaturan Jarak Tanam dan Cara Penyiangan Pada Pertanaman Kedelai. Prosiding Konferensi Himpunan Ilmu Gulma Indonesia. Ujung Pandang. Hal. 247250.

Effendi, S. 1991. Bercocok Tanam Jagung. CV.Yasaguna, Jakarta. 95 hal

Efendi, R. dan A.F. Fadhly. 2009. Pengaruh sistem pengolahan tanah dan pemberian pupuk NPKZn terhadap pertumbuhan dan hasil jagung. Risalah Penelitian Jagung dan Serelaia Lain. 9:15-22.

Elisa. 2012. Faktor Pembatas. http://elisa.ugm.ac.id/user/archive/download/27740/8606caa0c. Diakses pada 20 Maret 2019. 1-34 hal.

Gardner, F.P. 1991. Fisiologi Tanaman Budidaya. UI Press. Jakarta.

Haryati, Yati. dkk. 2015. Penerapan Pengelolaan Tanaman Terpadu JagungPada Beberapa Varietas Unggul Jagung Komposit di Kabupaten Majalengka. Jurnal Issn: 1410-0029 Agrin Vol.19,No.2. Balai Pengkajian Teknologi Pertanian (BPTP) Jawa Barat.

Hartatik, S. 2003. Peningkatan Ketahanan Varietas Jagung Manis (Zea Mays Saccharata Sturt) Terhadap Penyakit Bulai Melalui Seleksi Daur Ulang Fenotipe. Laporan PHB KI. Faperta. Universitas Jember. 
Hilal, Muhammad dan Memen Surahman. 2015. Daya Hasil dan Kualitas Jagung Manis Genotipe SD3 dengan Empat Varietas Pembanding di Kabupaten Bandung. Jurnal Bul. Agrohorti 3 (3) : 316 - 322. Departemen Agronomi dan Hortikultura, Fakultas Pertanian, Institut Pertanian Bogor.

Himawan. dan Supriyanto. 2003. Jagung. Pusat Penelitian dan Pengembangan Tanaman Pangan. Bogor.

Hinz, P.N., R. Shorter, P.A. Du Bose, and S.S. Yang. 1977. Probabilities of Selecting Genotypes when Testing at Several Locations. Crop Science, 17: 325-326.

I Wayan Sutresna, I Gusti Putu Muliartha Aryana, I Gde Eka Putra Gunartha. 2016. Evaluasi Genotipe Jagung (Zea Mays L.) Unggul Pada Lingkungan Tumbuh Dengan Perbaikan Teknologi Budidaya. Jurnal Seminar Nasional. Hal 678-682.

Kasriani dan Supadma. 2007. Pengaruh Pemberian Beberapa Dosis Pupuk (NPK) dan Jenis Pupuk Alternatif terhadap Hasil Tanaman Padi (Oryza sativa L.) dan Kadar N, P, K Inceptisol Selemadeg, Tabanan. Agritrop. Vol 26(4): 168- 176.

Kasryno, F. 2002. Perkembangan Poduksi Dan Konsumsi Jagung Dunia Selama Empat Decade dan Implikasinya Bagi Indonesia. Badan Litbang : Nasional Agribisnis Jagung.

Lingga, P dan Marson. 2009. Petunjuk Penggunaan Pupuk. Penebar Swadaya Jakarta.

Martojo.1992. Analisis Ragam, Heritabilitas dan Pendugaan Kemajuan Seleksi Populasi F2 dari Persilangan Kedelai Kultivar Slamet X Nokonsawon. Jurnal Tanaman Tropika. Vol 9(2) : 86-93.

Mayadewi, Ni Nyoman Ari. 2007. Pengaruh Jenis Pupuk Kandang dan Jarak Tanam terhadap Pertumbuhan Gulma dan Hasil Jagung Manis. Agritrop. Vol 24(4) : 153-159.

Moedjiono dan M. J. Mejaya. 1994. Variabilitas Genetik Beberapa Karakter Plasma Nutfah Jagung Koleksi Balittan Malang. Zuriat. Vol 5(2) : 27-32.

Mulyani, Eko Sri, dkk. Laporan Tahunan 2015 Penelitian dan Pengembangan Tanaman Pangan. Pusat Penelitian dan Pengembangan Tanaman Pangan Badan Penelitian Dan Pengembangan Pertanian.

Nuning Agro Subekti, Syarifuddin, Roy Effendi Dan Sri Sunarti. 2012. Morfologi Tanamandan Fase Pertumbuhan Jagung. Balai Penelitian Tanaman Serelia. Maros.

Pesireron, M. dan Senewe, R., E. 2011. 10 Varietas/Galur Jagung Komposit Dan Hibrida Pada Agroekosistem Lahan Kering di Maluku. Agrotrip Vol 7(2) : 53- 59.

Peter R. Goldsworthy dan N.M Fisher. 1992. Fisiologi Tanaman Budidaya (Terjemah dari The Physiologi Of Tropical Field Crops Oleh Tohari). Gadjah Mada University Press. Yogyakarta.

Purwono. 2005. Bertanam Jagung Unggul. Penebar Swadaya. Jakarta. 63 hal.

Puslitbangtan. 2009.Deskripsi Varietas Unggul Palawija1918-2009. Puslitbangtan Bogor.

Riwandi, Merakati Handajaningsih, Hasanudin. 2014. Teknik Budidaya Jagung dengan Sistem Organik di Lahan Marjinal. UNIB Press. Bengkulu.

Salisbury, F. B and C. Ross. 1969. Plant Phisiology. Belonout Co. Inc. California.

Sawardi dan Efendi, R. 2009. Efisiensi Penggunaan Pupuk N Pada Jagung Komposit Menggunakan Bagan Warna Daun. Prosiding Seminar Nasional Serealia. 108 - 115.

Saenong, S. 1988. Teknologi Benih Jagung. Pusat Penelitian dan Pengembangan Tanaman Pangan. Badan Penelitian dan Pengembangan Pertanian. Bogor. Shinta Eliestya P, Astri Anto, Suriansyah. 2014. Teknologi Budidaya Jagung dengan Pendekatan PTT. Balai Pengkajian Teknolgi Pertanian (BPTP). Kalimantan Tengah.

Saenong dan Subandi. 2002. Konsep PTT pada Tanaman Jagung. Makalah disampaikan pada Pembinaan Teknis dan Mangemen PTT Palawija di Balitkabi. Malang.

Sirrapa, M., dan Razak, N. 2010. Peningkatan Produktivitas Jagung Melalui Pemberian Pupuk N, P, K dan pupuk Kandang pada Lahan Kering di Maluku. Prosiding Pekan Serealia Nasional. Hal 277-286.

Sirrapa, M. dan Nurdin, M. 2010. Tanggapan Varietas Jagung Hibrida Dan Komposit Pada Pemberian Pupuk Tunggal N, P, K Dan Pupuk Kandang di Lahan Kering. JurnalAgrotropik. Vol 15(2): 49-55.

Sitompul, S. M. dan Guritno, B. 1995. Analisis Pertumbuhan Tanaman. UGM Press. Yogyakarta.

Soekirno, 1970. Teknik Produksi dan Pengembangan. Balai Penelitian Tanaman Serealia BALITSEREAL. Maros Ujung Pandang. 
Subandi dan Zubachtirodin. 2005. Peningkatan Efisiensi Pupuk NPK dan Produktivitas Jagung pada Lahan Kering Ultisol Kalimantan Selatan. Balai Penelitian Tanaman Serelia, Maros.

Subandi, Zubachtirodin, S. Saenong, W. Wakman, M. Dahlan, M. Mejaya, I.U. Firmansyah, dan Suryawati. 2002. Highlight Balai Penelitian Tanaman Serelia 2001. Balai Penelitian Tanaman Serelia. Maros. p. $8-9$.

Sudarmadji. 2007. Variasi Genetik, Heritabilitas dan Korelasi Genotipik Sifat SifatPenting Tanaman Wijen (Sesamum Indicum L.). Jurnal Littri, Vol. 13 No.3, September 2007 : 88 - 92.

Suherman, O dan Awaludin, H. 2007. Cara Memelihara Kemurnian Genetik dan Produksi Benih Jagung Komposit, Mendorong Petani Membuat Benih Bermutu Tinggi. Balai Penelitian Serelia, Maros, Sulawesi Selatan dan Balai Pengkajian Tanaman Pertanian, Nusa Tenggara Barat. Hal 1.

Sumarno. 1988. Dasar-dasar Ilmu Pemuliaan Tanaman. Pusat Antar Universitas Institut Pertanian Bogor. Bogor.

Supriono, 2006. Pengaruh Urea Tablet Dan Jarak Tanam Terhadap Pertumbuhan dan Hasil Kedelai Kultivar Sindoro. Fakultas Pertanian, Universiras Sebelas Maret, Surakarta. Hal : 1-10.

Sutoro, Yoyo Sulaeman dan Iskandar. 1988. Budidaya Tanaman Jagung. Puslitbang Tanaman Pangan. Bogor.

Syukur, M., S. Sujiprihati dan R. Yunianti. 2012. Teknik Pemuliaan Tanaman. Penebar Swadaya,348 hlm.

Wahyudin, A, Y. Yuwariah, F.Y Wicaksono, R.A.G. Bajri. 2017. Respon Jagung(Zea Mays L.) Akibat Jarak Tanam Pada Sistem Tanam Legowo (2:1) Dan Berbagai Dosis Pupuk Nitrogen Pada Tanah Inceptisol Jatinagor. Jurnal Kultivasi, Vol 16 (3): 508-512.

Wahyudiyanta, Imam. (2016, 20 Maret). Petani diedukasi Pola Tanam Terbaik Untuk Hasilkan Panen Melimpah. Dikutip 27 Juni 2019 dari Detik.com : http://m.detik.com/news/berita-jawatimur/d-3169465/petani-diedukasi-pola- tanam-terbaik-untuk-hasilkan-panen-melimpah.

Warisno. 1998. Jagung Hibrida. Kanisius. Yogyakarta. 